Volume 3 Nomor 1 Juli 2021:9-18

\title{
PENGARUH LAMA PENGUJIAN TERHADAP SERANGAN PENGGEREK KAYU DI \\ LAUT PADA KAYU MALAPOGA (Toona ciliata) DAN KAYU TEA (Artocarpus elasticus Reinw. Ex Blume)
}

\section{(The Effect Of Time Testing On The Attack Of Marine Borers At The Sea On Malapoga Timber \\ (Toona Ciliata) And Tea Wood (Artocarpus Elasticus Reinw. Ex Blume))}

\author{
Fauziah Ramadhana $^{1)}$, Abdul Hapid ${ }^{2)}$, Erniwati ${ }^{3)}$ \\ Jurusan Kehutanan, Fakultas Kehutanan, Universitas Tadulako,Jl. Soekarno Hatta Km.9 Palu, \\ Sulawesi Tengah 94118 \\ fauziahramadhana24@gmail.com
}

\begin{abstract}
Timber in brackish waters and at sea is often damaged by marine wood borer (marine borers). The wood used in boat building will of course often come in contact with sea water so that it does not rule out the attack of marine borers that will reduce the strength of the wood especially if it is used for a long time. The research objective was to determine the effect of the length of testing at sea on the strength (MOE and MOR) and the natural durability of Malapoga wood (Toona ciliata) and Tea wood (Artocarpus elasticus Reinw. Ex Blume). This research was conducted for 3 months at the Material Testing Laboratory, Faculty of Engineering and Agrotechnology Laboratory, Faculty of Agriculture, Tadulako University, while testing for marine borers was carried out in the waters of Talise Village, East Palu District, Palu City, Central Sulawesi. The test uses the Malapoga wood and Tea wood test samples with sizes $2 \mathrm{~cm} \times 2 \mathrm{~cm} \times 30 \mathrm{~cm}$. Meanwhile, at sea testing and data analysis using a completely randomized design (CRD) factorial pattern with 2 factors was repeated 5 times so that there were 30 samples with 10 test samples (control) without immersion in the sea. The results showed that the length of the test had a very significant effect on the strength of wood (MOE and MOR) and the natural durability of wood (weight loss percentage) and the types of Malapoga wood and Tea wood were classified in the strong class V (five).
\end{abstract}

Keywords : Malapoga Wood, Tea Wood, Marine borers.

\begin{abstract}
ABSTRAK
Kayu di perairan payau dan di laut sering kali mengalami kerusakan yang disebabkan oleh penggerek kayu di laut atau (marine borers). Kayu yang digunakan dalam pembuatan perahu tentunya akan sering bersentuhan dengan air laut sehingga tidak menutup kemungkinan serangan marine borers akan mengurangi kekuatan kayu apalagi jika digunakan dalam kurun waktu yang lama. Tujuan penelitian ialah untuk mengetahui pengaruh lama pengujian di laut terhadap kekuatan (MOE dan MOR) serta keawetan alami kayu Malapoga (Toona ciliata) dan kayu Tea (Artocarpus elasticus Reinw. Ex Blume). Penelitian ini dilaksanakan selama 3 bulan bertempat di Laboratorium Pengujian Bahan, Fakultas Teknik dan Laboratorium Agroteknologi, Fakultas Pertanian Universitas Tadulako, sedangkan untuk pengujian terhadap marine borers dilakukan di perairan Kelurahan Talise, Kecamatan Palu Timur, kota Palu, Sulawesi Tengah. Pengujian menggunakan contoh uji kayu Malapoga dan kayu Tea dengan ukuran $2 \mathrm{~cm}$ x $2 \mathrm{~cm}$ x $30 \mathrm{~cm}$. Sementara itu, pengujian di laut dan analisa data menggunakan Rancangan Acak Lengkap (RAL) pola faktorial dengan 2 faktor dilakukan ulangan sebanyak 5 kali sehingga terdapat 30 contoh uji dengan 10 contoh uji (kontrol) tanpa perendaman di laut. Hasil penelitian menunjukkan bahwa lama pengujian berpengaruh sangat nyata terhadap kekuatan kayu (MOE dan MOR) dan keawetan alami kayu (persentase kehilangan berat) serta jenis kayu Malapoga dan kayu Tea tergolong dalam kelas kuat V (lima).
\end{abstract}

Kata Kunci : Kayu Malapoga, Kayu Tea, Penggerek laut.

\section{PENDAHULUAN}

Indonesia merupakan negara kepulauan, sekitar $75 \%$ dari luas wilayahnya merupakan lautan. Panjang garis pantai Indonesia kurang lebih $81.000 \mathrm{~km}$ atau sekitar $14 \%$ dari panjang garis pantai di dunia serta 
mempunyai luas lautan sekitar 5,8 juta $\mathrm{km}^{2}$. Keadaan geografis yang demikian, menjadikan transportasi perairan laut menjadi vital dalam pemanfaatan sumberdaya lautnya. Hingga saat ini, sarana transportasi dan bangunan di laut yang digunakan masih sangat tergantung dari bahan baku kayu (Nugroho, 2007).

Pemanfaatan jenis-jenis kayu sebagai bahan baku pembuatan perahu di Indonesia sudah banyak dilaporkan. Namun pemanfaatan jenis-jenis sebagai bahan baku berbeda antara satu daerah dengan daerah yang lain. Hal ini selain perbedaan tempat tumbuh juga akibat perbedaan adat istiadat/budaya setempat (Rahawarin et.al., 2010).

Penggunaan kayu sebagai bahan utama pembuatan perahu tradisional sudah dilakukan semenjak zaman purba dimana bahkan terkenal kayu kapal Pinisi, kebutuhan kayu tidak dapat dipisahkan dari kehidupan masyarakat sehari-hari, baik untuk kebutuhan dalam rumah maupun luar rumah, seperti kontruksi rumah, perabot rumah tangga, pagar rumah, jembatan, serta berbagai alat transportasi kapal kayu, perahu dan gerobak (Batubara, 2002 dalam Riansah, 2015). Selain itu, kapal yang menjadi sarana angkutan bagi para nelayan juga masih menggunakan kayu (Rizki et. al., 2013).

Kayu yang digunakan dalam pembuatan perahu atau kapal-kapal tradisional harus memiliki beberapa persyaratan khusus untuk digunakan. Kapal yang dibuat dari kayu harus memiliki kekuatan tinggi dan ketahanan terhadap serangan organisme laut sehingga diharapkan dapat beroperasi dalam jangka waktu yang lama (Riansah, 2015).

Kriteria kayu yang baik digunakan sebagai bahan baku pembuatan perahu tradisional adalah kayu harus kuat, tidak mudah pecah, lurus, tahan terhadap serangan organisme perusak kayu khususnya binatang laut. Selait itu, kayu harus memiliki berat yang ringan agar memiliki daya apung yang cukup untuk digunakan sebagai perahu (Kurni, 2013 dalam Riansah, 2015).
Kapal atau perahu yang beroperasi di laut yang memiliki kadar air garam, menjadikan air laut sebagai akibat dari umur laminasi kayu yang pendek karena terjadinya korosi biologis yaitu pelapukan. Pelapukan adalah salah satu bnetuk bentuk korosi yang dapat mengurangi sifat fisik dari material tersebut (Kurniawan et.al., 2013).

Kayu yang digunakan untuk keperluan tersebut tentunya tidak luput dari serangan organisme penggerek di laut atau yang sering disebut dengan "marine borers". Organisme penggerek kayu di laut yang sering dijumpai yaitu dari golongan Mollusca dan Crustacea. Penyebaran organisme ini sangat luas dan dapat dijumpai baik di laut, pantai atau di perairan payau. Di daerah tropis organisme ini berkembang dengan pesat dan dapat dijumpai sepanjang tahun (Adam, 2015).

Sulawesi Tengah merupakan wilayah dimana sebagian besar masyarakatnya bermukim di wilayah pesisir, hal ini disebabkan karena wilayahnya mempunyai garis pantai terpanjang di Sulawesi. Oleh sebab itu masyarakat yang umumnya bermata pencaharian sebagai nelayan membangun rumah tinggal dan permukimannya pada tempat-tempat dimana dengan mudah dapat menyatu dan hidup dengan tempat yang dapat memberikan kehidupan (Mulyati dan Sarwadi, 2011).

Kebutuhan kayu dalam pembuatan perahu masih sering digunakan oleh para nelayan maupun masyarakat yang tinggal di pesisir pantai sebagai sarana transportasi mereka. Kayu yang digunakan dalam pembuatan perahu tentunya akan sering bersentuhan dengan air laut sehingga tidak menutup kemungkinan serangan penggerek kayu di laut akan mengurangi kekuatan kayu itu sendiri, apalagi jika digunakan dalam kurun waktu yang sangat lama.

Oleh karenanya, perlu dilakukan penelitian terhadap kekuatan (MOE dan MOR) serta keawetan alami kayu yaitu jenis kayu Malapoga (Toona ciliata) dan kayu Tea (Artocarpus elasticus Reinw. Ex Blume) 
yang sering digunakan sebagai bahan baku perahu oleh para nelayan maupun masyarakat di pesisir pantai.

Penelitian ini bertujuan untuk mengetahui pengaruh lama waktu pengujian di laut terhadap kekuatan (MOE dan MOR) serta keawetan alami kayu Malapoga (Toona ciliata) dan kayu Tea (Artocarpus elasticus Reinw. Ex Blume). Kegunaan dari penelitian ini diharapkan sebagai informasi tentang kekuatan (MOE dan MOR) serta keawetan alami kayu terhadap jenis kayu Malapoga (Toona ciliata) dan kayu Tea (Artocarpus elasticus Reinw. Ex Blume) terhadap serangan penggerek kayu di laut.

\section{METODE PENELITIAN}

Penelitian ini dilaksanakan selama tiga bulan dimulai bulan Desember 2018 sampai Maret 2019 bertempat di Laboratorium Pengujian Bahan, Fakultas Teknik dan Laboratorium Agroteknologi, Fakultas Pertanian, Universitas Tadulako. Pengujian contoh uji terhadap serangan penggerek kayu di laut dilakukan di perairan Kelurahan Talise, Kecamatan Palu Timur, Sulawesi Tengah.

Bahan yang digunakan dalam penelitian ini yaitu : Kayu Malapoga dengan ukuran 2 $\mathrm{cm}$ x $2 \mathrm{~cm}$ x $30 \mathrm{~cm}$; kayu Tea dengan ukuran $2 \mathrm{~cm} \times 2 \mathrm{~cm} \times 30 \mathrm{~cm}$; cat minyak dan parafin liquid.

Alat yang digunakan dalam penelitian ini yaitu adalah gelas beker, gelas ukur, benang, gergaji, meteran, tali, oven, desikator, mesin penguji mekanika kayu merk Baldwin satec sytem Inc. Type Universal Testing Machine Model 60 HVL-60000LB, kalkulator, laptop, kamera, dan alat tulis menulis.

Penelitian ini menggunakan Rancangan Acak Lengkap (RAL) pola faktorial dimana jenis kayu sebagai faktor $\mathbf{J}$ dan lama pengujian sebagai faktor L. Dengan demikian terdapat 6 perlakuan diulang sebanyak 5 kali ulangan, sehingga terdapat 6 x $5=30$ contoh uji untuk pengujian serangan penggerek kayu di laut. Dan 10 contoh uji (kontrol) tanpa perendaman di laut, sehingga terdapat 40 contoh uji dan 8 perlakuan.

Penelitian ini menggunakan kayu Malapoga (Toona ciliata) dan kayu Tea (Artocarpus elasticus Reinw. Ex Blume) sebagai bahan yang akan diujikan.

Setelah dibuat contoh uji, maka dilakukan pengukuran kadar air dan berat jenis sebagai berikut :

1. Kadar Air

Pengukuran kadar air kayu dilakukan sesuai metode Kasmudjo (2010).

a. Contoh uji berukuran $2 \mathrm{~cm} \times 2 \mathrm{~cm} \times 2$ $\mathrm{cm}$ ditimbang untuk mengetahui berat kering udara (BKU).

b. Contoh uji dimasukkan ke dalam oven pada suhu $103 \pm 2{ }^{\circ} \mathrm{C}$ selama 48 jam.

c. Setelah 48 jam, contoh uji dimasukkan ke dalam desikator selama kurang lebih 15 menit.

d. Kemudian contoh uji ditimbang untuk mengetahui berat kering tanur (BKT) kayu.

e. Penentuan kadar air dihitung dengan rumus sebagai berikut :

$$
K A=\frac{B K U-B K T}{B K T} x 100 \%
$$

Dimana :

$$
\begin{aligned}
& \mathrm{KA}=\text { Kadar Air }(\%) \\
& \mathrm{BKU}=\text { Berat kering udara }(\mathrm{g}) \\
& \mathrm{BKT}=\text { Berat kering tanur }(\mathrm{g})
\end{aligned}
$$

2. Berat Jenis

Pengukuran berat jenis dilakukan sesuai metode Kasmudjo (2010).

a. Masukkan contoh uji ke dalam gelas ukur yang telas berisi larutan parafin liquid, kemudian diamkan selama 1 2 menit.

b. Angkat contoh uji dari gelas ukur dan angin-anginkan.

c. Setelah itu, masukkan contoh uji ke dalam gelas beker yang telah berisi air sebanyak $80 \mathrm{ml}$.

d. Amati dan catat penambahan volumenya $\left(\mathrm{V}_{\mathrm{b}}\right)$.

e. Setelah itu contoh uji dibersihkan dan dikeringkan selama 30 menit sebelum dimasukkan ke dalam oven. 
f. Contoh uji dimasukkan ke dalam oven pada suhu $103 \pm 2{ }^{\circ} \mathrm{C}$ selama 48 jam.

g. Setelah 48 jam, contoh uji dimasukkan ke dalam desikator selama kurang lebih 15 menit.

h. Kemudian contoh uji ditimbang untuk mengetahui berat kering tanur (BKT) kayu.

i. Penentuan berat jenis dihitung dengan rumus sebagai berikut :

$$
B J=\frac{B K T}{V_{b}} x 100 \%
$$

Dimana :

$$
\begin{array}{ll}
\mathrm{BJ} & =\text { Berat Jenis } \\
\mathrm{BKT} & =\text { Berat kering tanur }(\mathrm{g}) \\
\mathrm{V}_{\mathrm{b}} & =\text { Volume basah }\left(\mathrm{cm}^{3}\right)
\end{array}
$$

\section{Pengujian Sifat Mekanik (Kekakuan Lentur dan Kekuatan Lentur)}

Pengujian sifat mekanik didasarkan pada standar Amerika, yaitu American Society for Testing and Materials (ASTM) D 143-94 (Reapproved 2000) Standar Test Methods for Small Clear Specimens of Timber (Nugroho, 2007).

\section{Proses Pengujian Kayu terhadap Serangan Penggerek Kayu di Laut Contoh uji yang direndam di laut.}

a. Contoh uji yang berupa stik berukuran 2 $\mathrm{cm} \times 2 \mathrm{~cm}$ x $30 \mathrm{~cm}$ dimasukkan ke dalam oven dengan suhu $103 \pm 2{ }^{0} \mathrm{C}$ selama 48 jam.

b. Contoh uji ditimbang beratnya sebelum dilakukan pengujian terhadap serangan penggerek kayu di laut (Marine borers).

c. Untuk pengujian terhadap penggerek kayu di laut, kayu terlebih dahulu disusun/diikatkan satu sama lainnya.

d. Contoh uji yang telah disusun/diikatkan satu sama lainnya dimasukkan ke dalam air laut menggunakan pemberat (untuk menjaga kemungkinan terbawa arus laut).

e. Pengambilan contoh uji dan pengamatan sesuai perlakuan yaitu 4 minggu, 8 minggu dan 12 minggu ( 3 bulan).

f. Contoh uji diangkat, dibersihkan permukaannya dan dijemur (stabil). g. Kemudian contoh uji dikeringkan dalam oven dengan suhu $103 \pm 2{ }^{\circ} \mathrm{C}$ selama 48 jam.

h. Selanjutnya contoh uji diambil (distabilkan suhunya) dan dilakukan penilaian terhadap persentase kehilangan berat

i. Persentase kehilangan berat dapat diperoleh melaui rumus sebagai berikut :

Dimana :

$$
a=\frac{m_{b}-m_{s}}{m_{b}} \times 100 \%
$$

a = Kehilangan berat (\%)

$\mathrm{m}_{\mathrm{s}}=$ massa contoh uji sesudah diujikan $(\mathrm{g})$

$\mathrm{m}_{\mathrm{b}}=$ massa contoh uji sebelum diujikan $(\mathrm{g})$

\section{Pengujian Sifat Mekanika Kayu setelah Perendaman}

Kekakuan lentur dan kekuatan lentur. Pengujian kekakuan dan kekuatan lentur menggunakan metode one point loading. Metode ini meletakkan beban di tengahtengah contoh uji yang terletak horizontal. Nilai kekakuan lentur dapat dihitung dengan rumus sebagai berikut :

$$
M O E=\frac{(\Delta P)\left(L^{3}\right)}{4(\Delta d) b h^{3}}
$$

Dimana :

$$
\begin{aligned}
\mathrm{MOE} & =\text { Kekakuan lentur }\left(\mathrm{kg} / \mathrm{cm}^{2}\right) \\
\Delta \mathrm{d} & =\text { selisih defleksi }(\mathrm{cm}) \\
\Delta \mathrm{P} & =\text { selisih beban pada daerah proporsi } \\
& (\mathrm{kg}) \\
\mathrm{b} & =\text { lebar contoh uji }(\mathrm{cm}) \\
\mathrm{L} & =\text { jarak sangga }(\mathrm{cm}) \\
\mathrm{H} & =\text { tebal contoh uji }(\mathrm{cm})
\end{aligned}
$$

Sedangkan nilai kekuatan lentur dapat dihitung menggunakan rumus sebagai berikut :

Dimana :

$$
M O R=\frac{3 P L}{2 b h^{2}}
$$

$$
\begin{array}{ll}
\mathrm{MOR} & =\text { Kekuatan lentur }\left(\mathrm{kg} / \mathrm{cm}^{2}\right) \\
\mathrm{B} & =\text { lebar contoh uji }(\mathrm{cm}) \\
\mathrm{P} & =\text { Beban maksimum saat kayu rusak } \\
& (\mathrm{kg}) \\
\mathrm{h} & =\text { tebal contoh uji }(\mathrm{cm}) \\
\mathrm{L} & =\text { Jarak sangga }(\mathrm{cm})
\end{array}
$$




\section{Analisis Data}

Model linear untuk Rancangan Acak Lengkap dengan dua faktor adalah (Gaspersz, 1991) :

$$
Y i j k=\mu+\alpha \mathbf{i}+\beta \mathbf{j}+(\beta \mathbf{j})_{i j}+\varepsilon i j k
$$

Dimana:

Yijk =Nilai pengamatan pada unit percobaan ke-k yang memperoleh kombinasi perlakuan $\alpha \mathrm{i}$ dan $\beta \mathrm{j}$

$\mathrm{M}=$ Nilai rataan

$\alpha \mathrm{i}=$ Pengaruh faktor $\mathrm{J}$

$\beta \mathrm{j}=$ Pengaruh faktor $\mathrm{L}$

$(\beta \mathrm{j})_{\mathrm{ij}}=$ Pengaruh interaksi antara faktor J dan

faktor $\mathrm{L}$

$$
\text { Eijk = Galat percobaan }
$$

Data hasil penelitian yang diperoleh selanjutnya dianalisis keragamannya dengan menggunakan analisis sidik ragam. Apabila pengujian dengan sidik ragam menunjukkan pengaruh yang nyata ( $\mathrm{F}$ hitung $>\mathrm{F}$ tabel) maka diadakan uji lanjut. Menurut Hanafiah (2005), jika nilai KK $(<10 \%)$ maka dilanjutkan dengan uji Beda Nyata Jujur (BNJ) dan apabila nilai KK (>10\%) maka dilanjutkan dengan uji Beda Nyata Terkecil (BNT).

\section{HASIL DAN PEMBAHASAN}

\section{Sifat Fisika Kayu}

Data hasil pengukuran nilai kadar air dan berat jenis dari kedua jenis kayu dapat dilihat pada Tabel 1.

Tabel 1. Nilai Rataan Kadar Air dan Berat Jenis dari Dua Jenis Kayu

\begin{tabular}{lcc}
\hline \multicolumn{1}{c}{ Jenis Kayu } & Kadar Air (\%) & Berat Jenis \\
\hline $\begin{array}{l}\text { Kayu Malapoga } \\
\text { (Toona ciliata) }\end{array}$ & 15,157 & 0,63 \\
\hline $\begin{array}{l}\text { Kayu Tea } \\
\text { (Artocarpus } \\
\text { elasticus Reinw. } \\
\text { Ex Blume) }\end{array}$ & 25,105 & 0,58 \\
\hline
\end{tabular}

Pada kayu Malapoga berada dalam kondisi air yang seimbang, keadaan kayu yang demikian menurut Kasmudjo (2010) dikatakan dalam kondisi kering air, kering udara atau dalam kondisi air seimbang (EMC) yang sesuai dengan standar kadar air kering angin di Indonesia rata-rata $10-18$
\%. Sedangkan pada kayu Tea berada dalam kondisi titik jenuh serat, dimana air bebasnya telah hilang sehingga yang tertinggal hanya air terikatnya saja. Menurut Kasmudjo (2010) bahwa titik jenuh serat pada umumnya berada pada KA $25-30 \%$.

Kadar air yang dimiliki oleh kayu berfluktuatif, hal ini dikarenakan kayu memilliki sifat higroskopis dimana sifat ini mempengaruhi kemampuan kayu untuk melepas dan mengikat kandungan air dari udara sekitar. Faktor yang mempengaruhi sifat ini adalah suhu dan kelembaban relatif dari udara sekitar (Nugroho, 2007).

Besarnya berat jenis pada tiap-tiap kayu berbeda-beda dan tergantung pada kandungan zat-zat dalam kayu, kandungan ekstraktif serta kandungan air kayu. Menurut Brwon et. al., (1952) dalam fauzan (2009) menyatakan bahwa berat jenis kayu bervariasi diantara berbagai jenis pohon dan diantara pohon dari satu jenis yang sama. Variasi ini juga terjadi pada posisi yang berbeda dari satu pohon. Adanya variasi berat jenis kayu disebabkan oleh perbedaan dalam jumlah zat penyusun dinding sel dan kandungan zat ekstraktif per unit volume.

Berdasarkan volume basahnya, berat jenis kayu akan mencerminkan berat kayunya, sehingga klasifikasi kayu dengan kategori berat bila berat jenisnya $>0,56$ (Soenardi, 1976 dalam Kasmudjo, 2010). Hal ini menunjukkan bahwa kedua jenis kayu tersebut berada dalam kategori jenis kayu berat.

\section{Sifat Mekanika Kayu Kekakuan Lentur (MOE)}

Rataan nilai kekakuan lentur (MOE) pada jenis kayu Malapoga (Toona ciliata) dan kayu Tea (Artocarpus elasticus Reinw. Ex Blume) pada perbedaan pengujian (4 minggu, 8 minggu dan 12 minggu) dapat dilihat pada Gambar 1. 


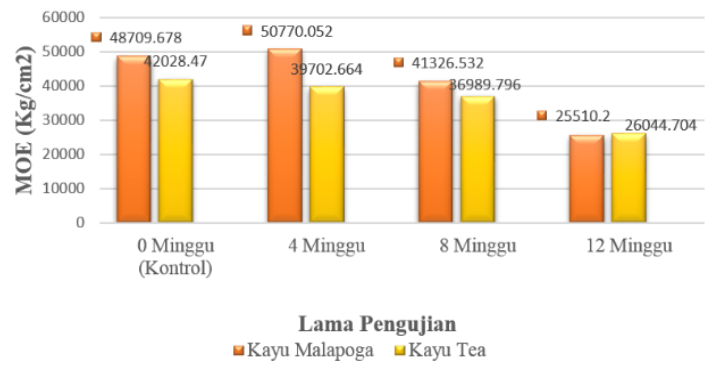

Gambar 1. Nilai Rataan Kekakuan Lentur (MOE)

Hasil pengujian MOE pada jenis kayu Malapoga (Toona ciliata) setelah pengujian 4 minggu, 8 minggu dan 12 minggu memiliki nilai sebesar $50770,052 \mathrm{Kg} / \mathrm{cm}^{2}, 41326,532$ $\mathrm{Kg} / \mathrm{cm}^{2}$ dan $25510,2 \mathrm{Kg} / \mathrm{cm}^{2}$, sedangkan pada kontrol memiliki nilai sebesar 48709,678. Untuk jenis kayu Tea (Artocarpus elasticus Reinw. Ex Blume) setelah pengujian 4 minggu, 8 minggu dan 12 minggu memiliki nilai sebesar 39702,664 $\mathrm{Kg} / \mathrm{cm}^{2}, 36989,796 \mathrm{Kg} / \mathrm{cm}^{2}$ dan 26044,704 $\mathrm{Kg} / \mathrm{cm}^{2}$, sedangkan pada kontrol memiliki nilai sebesar 42028,47 Kg/cm ${ }^{2}$.

Kekuatan kayu gubal berbeda dengan kayu teras, kayu bagian pangkal berbeda kekuatannya dengan bagian pucuk. Bagian pangkal batang memiliki sifat fisis dan mekanis yang lebih baik dibandingkan dengan bagian tengah dan ujung, sedangkan untuk bagian tepi batang memiliki sifat fisis dan mekanis yang lebih baik dibandingkan bagian tengah dan dalam (Iswanto et.al, 2010).

Berdasarkan Gambar 1 terjadi penurunan nilai MOE pada pengujian 4 minggu, 8 minggu dan 12 minggu terhadap kedua jenis kayu tersebut. Penurunan nilai MOE ini sebagian besar diakibatkan oleh penggerek kayu di laut. Muslich dan Sumarni (1998) dalam Nugroho (2007) menyatakan, marine borers secara terus menerus memperpanjang lubang gereknya di dalam kayu, besar saluran lubang gerak sesuai dengan besar tubuhnya. Besar dan bentuk lubang gerek akibat serangan penggerek tersebut yang terdapat dalam kayu tergantung oleh kepadatan populasi di dalam kayu. Apabila serangan yang diderita kayu sangat berat, maka saluran yang dibuatnya menjadi tidak beraturan sehingga menyerupai sarang lebah. Arah lubang gerek sejajar dengan arah serat kayu. Sementara itu, setengah kayu bagian atas ketika diuji untuk mendapatkan nilai MOE dan MOR, akan mengalami tegangan tekan dan setengah kayu bagian bawah mengalami tegangan tarik. Untuk mengetahui adanya perbedaan perlakuan jenis kayu dan lama pengujian terhadap kekakuan lentur (MOE) pada jenis kayu Malapoga (Toona ciliata) dan kayu Tea (Artocarpus elasticus Reinw. Ex Blume) maka dilakukan analisis sidik ragam (ANOVA) yang hasilnya dapat dilihat pada Tabel 2.

Tabel 2. Analisis Sidik Ragam (ANOVA)

\begin{tabular}{|c|c|c|c|c|c|c|}
\hline \multirow{2}{*}{$\begin{array}{c}\text { Sumber } \\
\text { Keragaman }\end{array}$} & \multirow{2}{*}{$\begin{array}{l}\text { Derajat } \\
\text { Bebas } \\
\text { (DB) }\end{array}$} & \multirow{2}{*}{$\begin{array}{c}\text { Jumlah } \\
\text { Kuadrat (JK) }\end{array}$} & \multirow{2}{*}{$\begin{array}{c}\text { Kuadrat } \\
\text { Tengah (KT) }\end{array}$} & \multirow[t]{2}{*}{ F. Hitung } & \multicolumn{2}{|c|}{ F. Tabel } \\
\hline & & & & & 0,05 & 0,01 \\
\hline Perlakuan & 7 & 3008200447,455 & 429742921,065 & $13429466,283^{*}$ & 2,32 & 3,25 \\
\hline $\mathrm{J}$ & 1 & 290273867,178 & 290273867,178 & $2,550^{\text {th }}$ & 4,15 & 7,50 \\
\hline $\mathrm{L}$ & 3 & 2542653969,501 & 847551323,167 & $7,447^{*+}$ & 2,90 & 4,46 \\
\hline JL & 3 & 175272610,776 & 58424203,592 & $0,513^{\text {th }}$ & 2,90 & 4,46 \\
\hline Galat & 32 & 3641731805,2 & 113804118,912 & & & \\
\hline Total & 39 & & & & & \\
\hline
\end{tabular}

Keterangan $: * *=$ Berpengaruh sangat nyata $\mathrm{tn}=$ Tidak berpengaruh nyata

Dari tabel ANOVA di atas memperlihatkan bahwa lama pengujian berpengaruh sangat nyata terhadap kekakuan lentur (MOE) contoh uji, sedangkan pada jenis kayu dan interaksi perlakuan antara jenis kayu dan lama pengujian tidak berpengaruh nyata terhadap kekakuan lentur (MOR) contoh uji. Sehingga hasil ini menunjukkan bahwa faktor $\mathbf{J}$ (jenis kayu) dan interaksi antara jenis kayu dan lama pengujian tidak memberikan pengaruh terhadap kekakuan lentur (MOE). Untuk mengetahui perbedaan perlakuan maka dilakukan uji Beda Nyata Terkecil (BNT).

Tabel 3. Hasil Beda Nyata Terkecil (BNT) Lama Pengujian terhadap MOE 


\begin{tabular}{ccc}
\hline Perlakuan & Rerata & $\begin{array}{c}\text { BNT } \\
5 \%\end{array}$ \\
\hline L1 & $45236,358^{\mathrm{a}}$ & 13844,788 \\
\hline L2 & $39158,164^{\mathrm{ab}}$ & \\
\hline L3 & $25777,452^{\mathrm{b}}$ & \\
\hline
\end{tabular}

Ket: Angka-angka yang diikuti oleh huruf yang tidak sama pada kolom yang sama berarti berbeda nyata pada taraf uji BNT 5\%.

\section{Kekuatan Lentur (MOR)}

Rataan nilai kekuatan lentur (MOR) pada jenis kayu Malapoga (Toona ciliata) dan kayu Tea (Artocarpus elasticus Reinw. Ex Blume) pada perbedaan pengujian (4 minggu, 8 minggu dan 12 minggu) dapat dilihat pada Gambar 2.

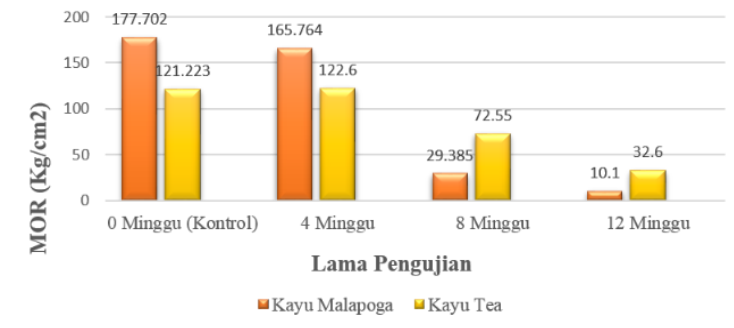

Gambar 2. Nilai Rataan Kekuatan Lentur (MOR)

Hasil pengujian MOR pada jenis kayu Malapoga (Toona ciliata) setelah pengujian 4 minggu, 8 minggu dan 12 minggu memiliki nilai sebesar $165,764 \mathrm{Kg} / \mathrm{cm}^{2}, \quad 29,395$ $\mathrm{Kg} / \mathrm{cm}^{2}$ dan $10,1 \mathrm{Kg} / \mathrm{cm}^{2}$, sedangkan pada kontrol memiliki nilai sebesar 177,702 $\mathrm{Kg} / \mathrm{cm}^{2}$. Untuk jenis kayu Tea (Artocarpus elasticus Reinw. Ex Blume) setelah pengujian 4 minggu, 8 minggu dan 12 minggu memiliki nilai sebesar $122,6 \mathrm{Kg} / \mathrm{cm}^{2}$, $72,55 \mathrm{Kg} / \mathrm{cm}^{2}$ dan $32,6 \mathrm{Kg} / \mathrm{cm}^{2}$, sedangkan pada kontrol memiliki nilai sebesar 121, 223 $\mathrm{Kg} / \mathrm{cm}^{2}$.

Berdasarkan Gambar 2 terjadi penurunan nilai MOR pada perlakuan 4 minggu, 8 minggu dan 12 minggu terhadap kedua jenis kayu tersebut. Hal ini diakibatkan oleh serangan penggerek kayu di laut maupun perendaman di laut yang menyebabkan semakin kecilnya sifat kekuatan lentur pada kedua kayu tersebut. Perbedaan perubahan kekuatan yang terjadi sesuai dengan waktu lamanya pengujian. Perendaman yang berlangsung selama 4 minggu tidak menunjukkan penurunan MOR secara signifikan (sesuai kontrol), berbeda halnya dengan perendaman yang berlangsung selama 12 minggu, kedua jenis kayu tersebut mengalami penurunan yang signifikan (sesuai kontrol). Dengan lamanya pengujian, akan lebih memudahkan penggerek kayu di laut masuk ke dalam kayu tersebut, baik untuk dijadikan tempat tinggal ataupun sebagai bahan makanan.

Untuk mengetahui adanya perbedaan perlakuan jenis kayu dan lama pengujian terhadap kekuatan lentur (MOR) pada jenis kayu Malapoga (Toona ciliata) dan kayu Tea (Artocarpus elasticus Reinw. Ex Blume) maka dilakukan analisis sidik ragam (ANOVA) yang hasilnya dapat dilihat pada Tabel 4.

Tabel 4. Analisis Sidik Ragam (ANOVA) pada Modulus of Rupture (MOR)

\begin{tabular}{ccccccc}
\hline $\begin{array}{c}\text { Sumber } \\
\text { Keragaman }\end{array}$ & $\begin{array}{c}\text { Derajat } \\
\text { Bebas } \\
\end{array}$ & $\begin{array}{c}\text { Jumlah } \\
\text { Kuadrat }\end{array}$ & $\begin{array}{c}\text { Kuadrat } \\
\text { Tengah }\end{array}$ & F. Hitung & \multicolumn{2}{c}{ F. Tabel } \\
\cline { 6 - 8 } & $(\mathbf{J K})$ & & & & 0,05 & 0,01 \\
\hline Perlakuan & 7 & 145545,293 & 20792,184 & $649,755^{* *}$ & 2,32 & 3,25 \\
\hline J & 1 & 721,574 & 721,574 & $0,821^{\text {tm }}$ & 4,15 & 7,50 \\
\hline L & 3 & 126989,386 & 42329,795 & $48,194^{* *}$ & 2,90 & 4,46 \\
\hline J & 3 & 17834,333 & 5944,777 & $6,768^{* *}$ & 2,90 & 4,46 \\
\hline Galat & 32 & 28106,213 & 878,319 & & & \\
\hline Total & 39 & & & & & \\
\hline
\end{tabular}

Keterangan : $* *=$ Berpengaruh sangat nyata

$$
\text { tn }=\text { Tidak berpengaruh nyata }
$$

Dari tabel ANOVA di atas memperlihatkan bahwa lama pengujian dan interaksi perlakuan antara jenis kayu dan lama pengujian berpengaruh sangat nyata terhadap kekuatan lentur (MOR) contoh uji, sedangkan pada jenis kayu tidak berpengaruh nyata terhadap kekuatan lentur (MOR) contoh uji. Sehingga hasil ini menunjukkan bahwa faktor $\mathrm{J}$ (jenis kayu) pengaruhnya ditingkatkan oleh faktor L (lama pengujian) maka dari itu jenis kayu memiliki pengaruh tidak nyata terhadap kekuatan lentur (MOR). Untuk mengetahui perbedaan antara perlakuan maka dilakukan uji lanjut terkecil (BNT). 
Tabel 5. Hasil Beda Nyata Terkecil Lama Pengujian terhadap MOR

\begin{tabular}{ccc}
\hline Perlakuan & Rerata & $\begin{array}{c}\text { BNT } \\
5 \%\end{array}$ \\
\hline L1 & $144,182^{\mathrm{a}}$ & 38,273 \\
\hline L2 & $50,967^{\mathrm{b}}$ & \\
\hline L3 & $21,350^{\mathrm{b}}$ & \\
\hline
\end{tabular}

Ket: Angka-angka yang diikuti oleh huruf yang tidak sama pada kolom yang sama berarti berbeda nyata pada taraf uji BNT 5\%.

Tabel 6. Hasil Beda Nyata Terkecil Interaksi Antara Jenis Kayu dan Lama Pengujian terhadap MOR

\begin{tabular}{ccc}
\hline Perlakuan & Rerata & $\begin{array}{c}\text { BNT } \\
5 \%\end{array}$ \\
\hline J1L0 & $177,702^{\mathrm{a}}$ & 38,273 \\
\hline J1L1 & $165,764^{\mathrm{a}}$ & \\
\hline J2L1 & $122,600^{\mathrm{b}}$ \\
\hline J2L0 & $121,223^{\mathrm{b}}$ \\
\hline J2L2 & $72,55^{\mathrm{c}}$ \\
\hline J2L3 & $32,600^{\mathrm{d}}$ \\
\hline J1L2 & $29,385^{\mathrm{d}}$ \\
\hline J1L3 & $10,100^{\mathrm{d}}$ \\
\hline
\end{tabular}

Ket: Angka-angka yang diikuti oleh huruf yang tidak sama pada kolom yang sama berarti berbeda nyata pada taraf uji BNT 5\%.

\section{Keawetan Alami Kayu}

Keawetan alami pada suatu jenis kayu terhadap serangan marine borers dapat dilihat dari kehilangan berat, semakin besar kehilangan berat contoh uji akan menunjukkan bahwa kayu tersebut dikatakan tidak awet (Adam, 2015). Hasil penelitian pada dua jenis kayu yaitu kayu Malapoga (Toona ciliata) dan kayu Tea (Artocarpus elasticus Reinw. Ex Blume) terhadap serangan penggerek kayu di laut untuk mengetahui persentase kehilangan berat dari kedua jenis kayu tersebut dengan lama pengujian 4 minggu, 8 minggu dan 12 minggu, dapat dilihat pada Gambar 3.

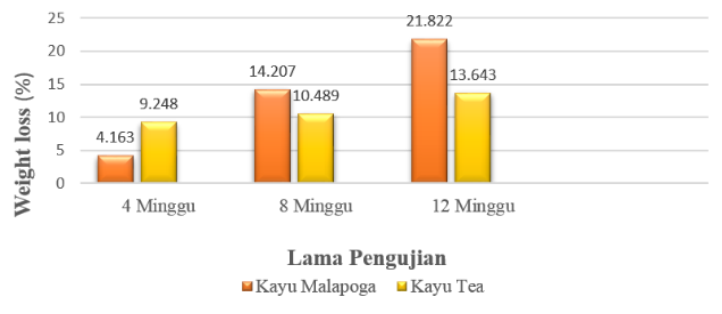

Gambar 3. Persentase kehilangan berat jenis kayu Malapoga dan kayu Tea dengan lama pengujian 4 minggu, 8 minggu dan 12 minggu

Hasil penelitian terhadap persentase kehilangan berat pada jenis kayu Malapoga (Toona ciliata) dengan lama pengujian 4 minggu, 8 minggu dan 12 minggu memiliki nilai sebesar 4,163\%, 14, 207\% dan 21, $822 \%$, sedangkan pada jenis kayu Tea (Artocarpus elasticus Reinw. Ex Blume) dengan lama pengujian yang sama memiliki nilai sebesar $9,248 \%, 10,489 \%$ dan 13 , 643\%.

Penurunan kehilangan berat pada kedua jenis kayu tersebut, khususnya pada kayu Malapoga (Toona ciliata) karena memiliki selang kehilangan berat yang relatif tinggi dibanding dengan kayu Tea (Artocarpus elasticus Reinw. Ex Blume), menujukkan bahwa kayu Malapoga (Toona ciliata) memiliki kandungan selulosa yang tinggi yang disukai oleh organisme perusak kayu sehingga zat-zat yang terkandung di dalam kayu habis dimakan oleh perusak kayu tersebut dan mengurangi bobot kayu saat pengujian kehilangan berat serta saat pengujian mekanika kayu (MOE dan MOR). Hal ini sesuai dengan Turner (1996) dalam Muslich dan Rulliaty (2013) bahwa intensitas serangan pada contoh uji disebabkan karena adanya perbedaan komponen kimia pada kayu. Komponen kayu berupa selulosa lebih disukai oleh famili Teredinidae karena sebagai sumber makanannya, sehingga kayu yang banyak mengandung selulosa akan mendapat serangan lebih berat (Muslich dan Sumarni, 1988 dalam Muslich dan Rulliaty, 2013).

Faktor utama yang menentukan ketahanan alami kayu yaitu adanya zat ekstraktif yang bersifat sebagai fungisida dalam kayu, insektisida atau zat lain yang sifatnya racun. Zat ekstraktif yang sifatnya racun terhadap salah satu organisme perusak belum tentu bersifat racun terhadap organisme perusak lainnya. Maka ketahanan 
alami kayu cenderung bersifat relatif, tergantung kepada organisme yang menyerangnya, biasanya tergantung dimana kayu tersebut akan dipergunakan (Brasto, 2007 dalam Adam, 2015).

Keawetan merupakan sifat kayu yang penting karena walaupun kelas kuatnya tinggi, tetapi manfaatnya akan banyak berkurang bila umur pakainya pendek. Umur pakai yang pendek sangat merugikan, karena biaya yang dikeluarkan tidak seimbang dengan umur pakainya. Sifat keawetan suatu jenis kayu dapat dipakai untuk bahan pertimbangan dalam mengambil keputusan apakah jenis kayu tersebut perlu diawetkan atau tidak apabila dipakai untuk keperluan tertentu.

Keawetan alami suatu kayu di tentukan oleh zat ekstraktif yang bersifat racun terhadap factor perusak kayu sehingga dengan sendirinya keawetan alami kayu akan bervariasi sesuai dengan variasi jumlah dan macam zat ekstraktif. Makin banyak zat ekstraktif dalam kayu, maka makin awet kayu tersebut. Jenis kayu kayu yang berbeda mempunyai keawetan alami yang berbeda pula (Adam, 2015).

Untuk mengetahui adanya perbedaan perlakuan jenis kayu dan lama pengujian terhadap kehilangan berat (weight loss) pada jenis kayu Malapoga (Toona ciliata) dan kayu Tea (Artocarpus elasticus Reinw. Ex Blume) maka dilakukan analisis sidik ragam (ANOVA), seperti Tabel 7.

Tabel 7. Analisis Sidik Ragam (ANOVA) Kehilangan Berat Contoh Uji pada Serangan Marine Borers

\begin{tabular}{|c|c|c|c|c|c|c|}
\hline \multirow{2}{*}{$\begin{array}{c}\text { Sumber } \\
\text { Keragaman }\end{array}$} & \multirow{2}{*}{$\begin{array}{c}\text { Derajat } \\
\text { Bebas } \\
\text { (DB) }\end{array}$} & \multirow{2}{*}{$\begin{array}{c}\text { Jumlah } \\
\text { Kuadrat } \\
\text { (JK) }\end{array}$} & \multirow{2}{*}{$\begin{array}{c}\text { Kuadrat } \\
\text { Tengah } \\
\text { (KT) }\end{array}$} & \multirow[t]{2}{*}{ F. Hitung } & \multicolumn{2}{|c|}{ F. Tabel } \\
\hline & & & & & 0,05 & 0,01 \\
\hline Perlakuan & 5 & 874,584 & 174,916 & $7,288^{* *}$ & 2,62 & 3,90 \\
\hline $\mathrm{J}$ & 1 & 38,674 & 38,674 & $3,049^{\text {tn }}$ & 4,26 & 7,82 \\
\hline $\mathrm{L}$ & 2 & 608,14 & 304,07 & $23,972^{* *}$ & 3,40 & 5,61 \\
\hline $\mathrm{JL}$ & 2 & 227,77 & 113,885 & $8,978^{* *}$ & 3,40 & 5,61 \\
\hline Galat & 24 & 304.423 & 12,684 & & & \\
\hline Total & 29 & & & & & \\
\hline
\end{tabular}

Keterangan : $* *=$ Berpengaruh sangat nyata

$$
\text { tn }=\text { Tidak berpengaruh nyata }
$$

Hasil analisis sidik ragam (ANOVA) menunjukkan bahwa lama pengujian dan interaksi antara jenis kayu dan lama pengujian berpengaruh sangat nyata terhadap kehilangan berat contoh uji, sedangkan pada jenis kayu tidak berpengaruh nyata terhadap kehilangan berat contoh uji. Sehingga hasil ini menunjukkan bahwa faktor $\mathbf{J}$ (jenis kayu) pengaruhnya ditingkatkan oleh faktor $\mathrm{L}$ (lama pengujian) maka dari itu jenis kayu memiliki pengaruh tidak nyata terhadap kehilangan berat. Hal ini juga menunjukkan bahwa perbedaan lama pengujian antara 4 minggu, 8 minggu dan 12 minggu memberikan pengaruh nyata terhadap contoh uji. Untuk mengetahui perbedaan antara perlakuan maka dilakukan uji lanjut terkecil (BNT).

Tabel 8. Hasil Beda Nyata Terkecil (BNT) Lama Pengujian terhadap Persentase Kehilangan Berat (\%)

\begin{tabular}{ccc}
\hline Perlakuan & Rerata & $\begin{array}{c}\text { BNT } \\
5 \%\end{array}$ \\
\hline L3 & $17,733^{\mathrm{a}}$ & 4,648 \\
\hline L2 & $12,348^{\mathrm{b}}$ & \\
\hline L1 & $6,705^{\mathrm{c}}$ & \\
\hline
\end{tabular}

Ket: Angka-angka yang diikuti oleh huruf yang tidak sama pada kolom yang sama berarti berbeda nyata pada taraf uji BNT 5\%.

Tabel 9. Hasil Beda Nyata Terkecil (BNT) Interaksi Antara Jenis Kayu dan Lama Pengujian terhadap Persentase Kehilangan Berat (\%)

\begin{tabular}{ccc}
\hline Perlakuan & Rerata & $\begin{array}{c}\text { BNT } \\
5 \%\end{array}$ \\
\hline & $21,822^{\mathrm{a}}$ & 4,648 \\
\hline J1L3 & $14,207^{\mathrm{b}}$ & \\
\hline J1L2 & $13,643^{\mathrm{b}}$ & \\
\hline J2L3 & $10,489^{\mathrm{b}}$ & \\
\hline J2L2 & $9,248^{\mathrm{c}}$ & \\
\hline J2L1 & $4,163^{\mathrm{d}}$ & \\
\hline J1L1 &
\end{tabular}

Ket: Angka-angka yang diikuti oleh huruf yang tidak sama pada kolom yang sama berarti berbeda nyata pada taraf uji BNT 5\%. 


\section{SIMPULAN}

Berdasarkan hasil penelitian pada pengujian 2 jenis kayu yaitu kayu Malapoga (Toona ciliata) dan kayu Tea (Artocarpus elasticus Reinw. Ex Blume) terhadap kekuatan kayu (MOE dan MOR) serta keawetan alami kayu akibat serangan marine borers, maka dapat disimpulkan bahwa lama pengujian berpengaruh terhadap kekuatan (MOE dan MOR) serta keawetan alami kayu dikarenakan serangan penggerek kayu di laut.

\section{DAFTAR PUSTAKA}

Adam Y. 2015. Uji Keawetan Alami Beberapa Jenis Kayu Terhadap Penggerek Kayu di Laut (Marine Borers) [Skripsi]. Palu: Fakultas Kehutanan, Universitas Tadulako.

Fauzan, Kurniawan R., Sari SM. 2009. Studi Pengaruh Kondisi Kadar Air Kayu Kelapa Terhadap Sifat Mekanis. Rekayasa Sipil 5(2) ISSN: 1858 2133

Gazpers V. 1991. Metode Perancangan Percobaan. Bandung: CV. Amico.

Hanafiah KA. 2005. Rancangan Percobaan. Edisi Ketiga. Palembang: Ali Press.

Iswanto AH, Sucipto T, Azhar I, Coto Z, Febrianto F. 2010. Sifat Fisis dan Mekanis Batang Kelapa Sawit (Elaeis gueenensis Jacq) Asal Kebun Aek Pancur-Sumatera Utara. Ilmu dan Teknologi Hasil Hutan 3(1): 1-7.

Kasmudjo. 2010. Teknologi Hasil Hutan Suatu Pengantar. Yogyakarta: Cakrawala Media.

Kasmudjo, 2010. Teknik Jitu Memilih Kayu untuk Aneka Penggunaan. Yogyakarta: Cakrawala Media.

Kurniawan A, Supomo H, Soejitno. 2013. Studi Pemilihan Jenis Coating Pada Komposit Bambu Laminasi Sebagai
Material Lambung Kapal. Teknik POMLIS 2 (1) ISSN: 2337 - 3539.

Mulyati A, Sarwadi A. 2011. Nilai-nilai Lokal pada Tipologi Rumah Tinggal Pemukiman Perairan di Sulawesi Tengah. Proseding Seminar Nasional The Local Tripod Akrab Lingkungan, Kearifan Lokal dan Kemandirian.

Muslich M. dan Rulliaty S. 2011. Kelas Awet 15 Jenis Kayu Andalan Setempat Terhadap Rayap Kayu Kering, Rayap Tanah, dan Penggerek di Laut. Penelitian Hasil Hutan 29(1): 67-77.

Muslich M, Rulliaty S, 2013. Keawetan Lima Puluh Jenis Kayu Terhadap Uji Kuburan dan Uji Laut. Penelitian Hasil Hutan 31(4): 250-257.

Nugroho A. 2007. Perubahan Sifat Fisik dan Sifat Mekanik Beberapa Jenis Kayu Akibat Serangan Penggerek Kayu di Laut di Perairan Pulau Gambut [Skripsi]. Bogor: Fakultas Kehutanan, Institut Pertanian Bogor.

Rahawarin YY, Sinaga NI, Liwang J. 2010. Pemanfaatan Jenis Kayu Sebagai Bahan Baku Pembuatan Perahu Tradisional di Pulau Ambai, Papua. Tropika, 2010 - $05-24$.

Riansah NAD. 2015. Identifikasi Jenis Kayu yang Dimanfaatkan untuk Pembuatan Perahu Tradisional Nelayan Muncar Kabupaten Banyuwangi dan Pemanfaatannya sebagai Buku Nonteks [Skripsi]. Jamber: Program Studi Pendidikan Biologi, Jurusan Pendidikan MIPA, Fakultas Keguruan dan Ilmu Pendidikan, Univrsitas Jamber.

Rizki ADF. 2013. Ketahanan Fiber Plastic Composite (FPC) Termodifikasi Terhadap Serangan Penggerek Laut (Marine Borer) [Skripsi]. Sumatera Utara: Program Studi Kehutanan, Fakultas Pertanian, Universitas Sumatera. 